\title{
1 Pros and cons of furrow irrigation on smallholdings in northeast Brazil
}

3 Danielle F. Araujo ${ }^{1}$, Raimundo N. Costa ${ }^{1}$ and Luciano Mateos ${ }^{2, *}$

4

$5 \quad{ }^{1}$ Departamento de Engenharia Agrícola, Universidade Federal do Ceará, Fortaleza, Brazil

6 2,*Instituto de Agricultura Sostenible, CSIC, Alameda del Obispo, Córdoba, Spain.

$7 \quad$ Corresponding author.E-mail: luciano.mateos@ias.csic.es

8

9 Keywords: smallholder irrigation; irrigation-induced erosion; irrigation application efficiency;

10 irrigation distribution uniformity; soil basic infiltration rate.

ABSTRACT

Smallholder farming is the basis of agricultural production in developing regions. Irrigation improves the household livelihood and welfare of smallholders. Furrow irrigation is the most common type of irrigation on the small farms of public irrigation schemes set up in the Northeast of Brazil during the 1970s and 1980s. However, furrow irrigation triggers environmental problems related to deep percolation, runoff and soil erosion. The objective of this research was to determine how soil was lost from irrigation furrows as a result of their management and performance. Experiments were carried out in the Curú-Pentecoste irrigation scheme located in the state of Ceará, Brazil. Three inflow rates (corresponding to the three sizes of syphons used to apply water to the furrows) were compared on 60-m long furrows in the two predominant soil classes (sandy loam and silty clay loam) during 4 or 5 irrigation events throughout the irrigation season. Runoff represented between 20 and $70 \%$ of the water applied, carrying sediments amounting up to $2.8 \mathrm{Mg} \mathrm{ha}^{-1}$ in 4 irrigation events. Simple irrigation practices that could improve furrow irrigation performance in the scheme are suggested. However, the environmental problems of the furrow irrigation in practice seem inherent to the irrigation method used under those conditions. The paper discusses the adoption and performance of traditional and modern irrigation technology in smallholdings in developing regions. 
Worldwide, over 324 million hectares were equipped for irrigation in 2012, of which about 275 million ha were actually irrigated (FAO, 2016). Localized and sprinkler irrigation accounted for only about $14 \%$ of this area, the remaining area being systematized for surface irrigation methods (FAO, 2016), that include furrow, border and basin irrigation. The first of these is the most common type of surface irrigation for row crops on small farms in developing regions (Kay, 1986).

Smallholder farming is the basis of agricultural production in developing countries. At least $90 \%$ of farms in the world are family farms, occupying between $50 \%$ (Graeub et al., 2016) and $75 \%$ (Lowder et al., 2016) of the world's agricultural land. The number of these farms that have irrigation is unascertained, but it is well known that irrigation improves household livelihood and welfare of smallholders (Hussain and Hanjra, 2004; Connor et al., 2008; Hanjra et al., 2009; Hussain, 2007; Comas et al., 2012; Burney et al., 2013; Burney et al., 2014).

The Brazilian public irrigation schemes (schemes funded by the government) concentrated in the semi-arid Northeast, occupy 219,000 ha of a total of 7 million ha, and serve a large number of smallholders in one of Brazil's poorest regions (ANA, 2017). However, public schemes are stigmatized for their poor performance and while irrigation (public plus private) in Brazil is expanding at a rate of about $5 \% / y$ (probably the highest rate worldwide), the area of public schemes has only increased by about $2 \% / y$ (ANA, 2017). Gonçalves et al. (2015) evaluated a large sample of these schemes finding a great variation in their performance, that they attributed to the predominant type of the on-farm irrigation system. Micro irrigation (surface drip and micro-sprinkler systems) was the principal system on the farms of the scheme that performed best, while the Curu-Pentecoste irrigation scheme showed the worst performance due to the preponderance of surface irrigation.

Supported by these and other findings, international scholars have claimed the excellence of micro irrigation for smallholders in Sub-Saharan Africa, Asia, and Latin America (Postel et al., 2001). However, recent studies are rebutting this claim (Wanvoeke et al., 2015; Venot et al., 2018). Mateos et al. (2018) have contributed to the debate with a case study in northeast Brazil. These authors evaluated irrigation performance on family farms of a modern public scheme where all the farms use micro irrigation. The study identified "technology translation" gaps that explained the overall poor performance of these modern micro irrigation systems. Determining the reasons for the ineffective performance, and the links to the appropriateness of the on-farm system selected, is crucial for sustainable and socially just irrigation development. Research on smallholder surface irrigation performance in Brazilian public irrigation schemes is therefore 
Although surface irrigation is the oldest irrigation method, the physical processes involved have only been mathematically formulated relatively recently (Strelkoff and Clemmens, 2007). Field measurements and hydraulic models have contributed to a better understanding of furrow irrigation performance itself (Bautista et al., 2009) and in comparison with other irrigation methods (Mateos, 2006). In furrow irrigation, the distribution of water across the field is simultaneous to its infiltration, which makes distribution uniformity and application efficiency highly dependent on the variability of soil characteristics (Bautista and Wallender, 1985; Izadi and Wallender, 1985; Oyonarte and Mateos, 2002). The inflow rate must be sufficient to ensure that water advances to the tail of the furrows in a reasonable time in order to allow sufficient water infiltration and uniformity throughout the field. As water flows along the furrows, it detaches soil particles that are transported downstream (Trout, 1996; Trout and Neibling, 1993; Fernández-Gómez et al., 2004; Mateos and Giráldez, 2005). Water that does not infiltrate runs off the field entering nearby water bodies. Therefore, furrow irrigation poses a number of environmental problems that include inefficiency, soil erosion, and water pollution.

The objective of this study is twofold. First, to contribute to the understanding of the erosion and soil loss processes in irrigation furrows, relating them to irrigation efficiency, infiltration uniformity, and the irrigation operation itself. Investigation on the erosion of irrigation furrows has been very scarce to date (King et al., 2015). This work provides new data in different soils and in the smallholder context, and does so following the approach used by Fernández-Gómez et al. (2004). Second, the discussion aims to contribute to the debate on which irrigation method is the most appropriate one for small farmers, introducing soil loss as an environmental performance criterion.

\section{Material and methods}

\subsection{The Curú-Pentecoste irrigation scheme}

The study case is the Curú-Pentecoste irrigation scheme (CPIS), located in the semiarid Brazilian North-East, in the state of Ceará (between latitudes $3^{\circ} 40^{\prime}$ and $3^{\circ} 51^{\prime} 18^{\prime \prime} \mathrm{S}$ and longitudes $39^{\circ} 10^{\prime} 19^{\prime \prime}$ and 39 $18^{\prime}$ '13' ' W, Fig. 1). The scheme was set up between 1974 and 1979, and it started operating in 1975. CPIS has a tropical climate with dry summers and rainfall concentrated between February and May (INMET, 2018). The mean annual rainfall is of $770 \mathrm{~mm}$. Soils, of an alluvial origin, are classified as Luvisols or Fluvic neosols (FAO, 2006), and have a silty clay loam or sandy loam texture. The main crops are banana, coconut, papaya and cowpea. Water is supplied by the General Sampaio and Pereira de Miranda reservoirs in the Curú River. Two main canals (P1 and P2, with a capacity of $1.8 \mathrm{~m}^{3} \mathrm{~s}^{-1}$ and $0.8 \mathrm{~m}^{3} \mathrm{~s}^{-1}$, 
respectively) divert water from the Serrota weir to convey it to the scheme. The water is distributed by gravity through secondary canals. The irrigable area in CPIS is 1180 ha and the area actually cultivated is 743 ha, of which 715 ha belong to 173 family farms with an average size of 4.13 ha. On-farm irrigation is by furrows. All the farmers belong to a cooperative in charge of the management, operation and maintenance of the scheme.

To characterize the on-farm irrigation, we conducted a field survey in eight farms. Farmers were questioned about irrigation turns, farm outlet flow rate, furrow characteristics (length, slope, grading), water application method (syphon, perforated pipe, others), irrigation equipment cost, furrow irrigation time, irrigation frequency and hydraulic head of the syphons.

\subsection{Experimental sites and treatments}

The experiments were conducted in two relatively flat sites of the Experimental Farm Curú Valley, located in CPIS. The sites selected represented the main soils in CPIS: sandy loam (Site 1) and silty clay loam (Site 2). Other soil characteristics are in Table 1.

The experimental period was July-October 2010 and 2012 in Sites 1 and 2, respectively. The furrows were planted with cotton in 2010 and left bare in 2012. There was no rainfall during the experimental periods. Mean reference evapotranspiration during the period of maximum cotton groundcover was estimated at $3.8 \mathrm{~mm}^{\text {day }}{ }^{-1}$ (mean value for September at the Guaramiranga station, the weather station in the CLIMWAT database nearest to CPIS; FAO, 2018), although in CPIS it is likely to be higher, because it is in the transition from the "Tropical savanna and dry climate (As)" to the "Hot semi-arid climate (BSh)", according to the Köppen-Geiger climate classification (Beck et al., 218). Assuming a crop coefficient of 1.1, net irrigation requirements $\left(Z_{r e q}, \mathrm{~mm}\right)$ of cotton for an irrigation interval of 8 days are $1.1 \times 3.8 \mathrm{~mm} \mathrm{day}^{-1} \times 8$ day $=34 \mathrm{~mm}$.

The length, spacing and slope of the furrows were selected based on the survey, with the aim of representing the typical characteristics of the furrows in CPIS. The area of the experimental plots was $1500 \mathrm{~m}^{2}$. Each plot consisted of 29 furrows 63-m long, 0.8-m apart (Fig. 2). Water was applied by syphons fed from a secondary canal, and runoff was collected in a drain ditch along the furrows' tail.

The treatments were the inflow rates given by syphons with diameters of $1,1.5$ or 2 inches (25.4, 38.1 and $50.8 \mathrm{~mm}$, respectively). Each treatment (named Q1, Q2, and Q3, respectively) consisted of seven adjacent furrows, three of which were monitored (alternating monitored and non-monitored furrows). Each 7-furrow set was flanked by pairs of non-irrigated furrows used to access to the measurement locations (Fig. 2). Cutoff time (the time at which the supply of water is interrupted, $t_{c o}$, min) was the advance time $\left(t_{a d v}\right.$, min) plus 40 minutes (based on the 


$$
D P R=100 \frac{V_{p}}{V_{a p p}}
$$

$$
E_{a}=100-T W R-D P R
$$

156

$$
E_{r}=100 \frac{V_{c}}{V_{r e q}}
$$


where $V_{\text {req }}(\mathrm{m} 3)$ is the volume of required water and the volumes of applied water $\left(V_{a p p}, \mathrm{~m}^{3}\right)$, runoff $\left(V_{r o}, \mathrm{~m}^{3}\right)$, infiltration $\left(V_{i n f}, \mathrm{~m}^{3}\right)$, percolation $\left(V_{p}, \mathrm{~m}^{3}\right)$ and crop available water $\left(V_{c}, \mathrm{~m}^{3}\right)$ were calculated as:

$$
V_{a p p}=\int_{0}^{t_{c o}} Q_{i n} d t
$$

161

$$
V_{\text {ro }}=\int_{t_{\text {adv }}}^{t_{\text {end }}} Q_{\text {out }} d t
$$

162

$$
V_{\text {inf }}=\int_{0}^{L} Z_{i n f} d l=V_{a p p}-V_{r o}
$$

163

$$
V_{p}=\int_{0}^{L} \max \left[\left(Z_{\text {inf }}-Z_{\text {req }}\right), 0\right] d l
$$

164

$$
V_{c}=\int_{0}^{L} \min \left[Z_{r e q}, Z_{\text {inf }}\right] d l
$$

The infiltrated depth was estimated at each $i$ th station $\left(Z_{i n f}, \mathrm{~m}^{3} \mathrm{~m}^{-1}\right)$ using Kostiakov-Lewis equation as in Walker and Skogerboe (1987):

$$
Z_{\text {inf }, i}=k\left(t_{r, i}-t_{a, i}\right)^{a}+f_{o}\left(t_{r, i}-t_{a, i}\right)
$$

where $f_{o}\left(\mathrm{~m}^{3} \mathrm{~m}^{-1} \mathrm{~min}^{-1}\right)$ is the basic infiltration rate and $k$ and $a$ are empirical parameters. The value of $f_{o}$ was estimated by dividing by $L$ the difference $Q_{\text {in }}-Q_{\text {out }}$ computed once the outflow rate was stabilized. The parameters $k$ and $a$ were obtained for each furrow/irrigation event using the WinSRFR surface irrigation analysis programme (Bautista et al., 2009; available at the USDA-ARS website http://www.ars.usda.gov/services/software/software.htm.). Furrow geometry, roughness parameter (Manning's roughness parameter was assumed to be equal to 0.04 for the first irrigation events and 0.02 for the successive events), and the inflow hydrograph were entered in WinSRFR and the values of $k$ and $a$ modified manually until matching the simulated and observed advance and recession trajectories while maintaining the simulated $V_{r o}$ equal to the measured $V_{r o}$. 
Infiltration uniformity was quantified with the indicator distribution uniformity $(D U, \%)$, the ratio of the average of the depths infiltrated in the quarter of the length of the furrow that receives the smallest depths and the average depth infiltrated along the entire length of the furrow (Burt et al., 1997):

$$
D U=100 \frac{4 V_{\text {inf }, l q}}{V_{\text {inf }}}
$$

183

where $V_{\text {inf,lq }}$ is the volume of water infiltrated in the quarter of the furrow length receiving the 185 smallest depths (low-quarter, indicated with the subscript $l q$ ):

$$
V_{i n f, l q}=\int_{\frac{3}{4} L}^{L} Z_{i n f} d l
$$

186

187 A sixth performance indicator was soil loss $\left(S L, \mathrm{Mg} \mathrm{ha}^{-1}\right)$ :

$$
S L=\frac{\int_{t_{\text {adv }}}^{t_{\text {end }}} C Q_{\text {out }} d t}{100 \mathrm{Ls}}
$$

188

189 where $C$ is the concentration of sediments in the runoff water expressed in $\mathrm{g} \mathrm{m}^{-3}$.

190 The integrals in Eqs. 5-9 and 12-13 were computed with the trapezoidal rule (Abramowitz and 191 Stegun, 1972).

192 All performance indicators were normalized to a target-infiltrated depth of $34 \mathrm{~mm}$ (the net 193 irrigation requirement; see section 2.2) at the tail of each monitored furrow for all irrigation 194 events. This was necessary to make the treatments comparable since irrigation time and 195 infiltrated depth varied from treatment to treatment, among furrows in the same treatment, and 196 among irrigation events. The target depth of $34 \mathrm{~mm}$ at the furrow tail was consistent with the 197 usual CPIS practice of allowing 40 min of runoff and implied $E_{r}=1$. 
201 The delivery schedule in CPIS is in turns, at intervals of eight days. Typically, the flow rate at

202 the farm outlets is about $2.4 \mathrm{~m}^{3} \mathrm{~min}^{-1}$, the duration of the turn about 12 hours, and the area

203 served by one outlet is about 2 ha. Therefore, the water depth that one farm outlet can supply

204 during an irrigation turn is $2.4 \mathrm{~m}^{3} \mathrm{~min}^{-1} \times 12 \mathrm{~h} \times 60 \mathrm{~min} \mathrm{~h}^{-1} \div 2 \mathrm{ha}=86 \mathrm{~mm}$.

205 The water is applied to the furrows directly from secondary canals using syphons with

206 diameters of $1,1.5$ or 2 inches (25.4, 38.1 and $50.8 \mathrm{~mm}$, respectively) and a length of about $2 \mathrm{~m}$.

207 The hydraulic head is around $0.2 \mathrm{~m}$. The most common furrow length varied between 80 and

$208100 \mathrm{~m}$ and the slope between 0.2 and $0.5 \%$. Grading was rare. Cutoff time was typically around

20940 minutes after the end of the advance phase.

210 The only irrigation equipment utilised are syphons, that are moved from furrow set to furrow set 211 and from field to field. Therefore, for the flow rate of $2.4 \mathrm{~m}^{3} \mathrm{~min}^{-1}$ at the farm outlet, the farmer

212 would need a set of about 40 syphons of one inch per farm outlet. The cost of a syphon is about

213 US\$ 6.00. Since the land in CPIS is relatively flat, furrow irrigation is done without grading or

214 levelling, or after little earth movement. Therefore, furrow irrigation management in CPIS is

215 inexpensive and simple once the irrigator has acquired some experience.

\subsection{The furrow irrigation process in the experimental sites}

217 Water that flows into the furrow head advances at a rate that depends on furrow slope, inflow

218 rate and soil infiltration characteristics. Fig. 3 depicts the process for one of the furrows on Site

219 1, during Irrigation I, under treatment Q1. Typically, the advance trajectory follows a potential

220 function (Fig 3a). After cutoff time, the water on the furrow recedes. Compared to the advance

221 trajectory, the recession trajectory is typically quite flat. [Recession in our experiments was

222 rapid, thus it was assumed to occur at cutoff time all along the furrow length (Fig. 3a).] While

223 water advances and recedes, it infiltrates into the soil. The infiltration opportunity time is

224 therefore greater at the head than at the tail, so that the infiltrated depth varies correspondingly

225 (Fig. 3b). This source of non-uniformity is inherent to furrow irrigation. Runoff starts when the

226 advance front reaches the furrow end (Fig. 3c). At that time, sediment concentration in the

227 runoff water is typically high, although it decreases rapidly as runoff progresses until reaching a

228 roughly constant value (Fig. 3c).

229 However, the furrow slope, inflow rate and soil infiltration characteristics are variable. Figure 4

230 shows the mean and variability of the longitudinal profile of the furrows monitored in Sites 1

231 and 2 . The total gradient in them was $0.47 \%$ and $0.32 \%$, respectively. The slope was quite

232 constant along the furrows in Site 2, but in Site 1 the slope at the furrow head and tail was

233 steeper than in the middle reach (Fig. 4). 
234 The mean inflow rate supplied by the syphons with diameters of $1,1.5$ and 2 inches was 0.042 ,

2350.105 and $0.165 \mathrm{~m}^{3} \mathrm{~min}^{-1}$, respectively. The inflow rate also varied significantly among furrows 236 and irrigations (range of variation $0.035-0.049,0.090-0.122,0.132-0.202 \mathrm{~m}^{3} \mathrm{~min}^{-1}$ in Q1, Q2,

237 and Q3, respectively), as depicted in the box plot chart of Figure 5. Various factors could cause

238 this variability, among which the difference in elevation between the water surface in the supply

239 canal and the syphon outlet would be the most important one.

240 The inflow rate treatments had a direct effect on advance time. The water flowed faster in

241 treatment Q3 (mean inflow rate of $0.165 \mathrm{~m}^{3} \mathrm{~min}^{-1}$ ) than in Q2 $\left(0.105 \mathrm{~m}^{3} \mathrm{~min}^{-1}\right)$, and in Q2 faster

242 than in Q1 $\left(0.042 \mathrm{~m}^{3} \mathrm{~min}^{-1}\right)$, although advance time was more sensitive to the inflow rate in its

243 lower range (Fig. 6). The intra-treatment variability of slope, inflow rate and soil characteristics

244 was translated into the variability of the advance time. Figure 6 shows advance time variability

245 from irrigation to irrigation for a given inflow rate treatment and the standard deviation bars

246 indicate variability among the furrows of each treatment and irrigation event.

247 The advance time was a little longer than runoff time (40 $\mathrm{min}$ ) in Q1 (mean advance time in Q1

248 was $47 \mathrm{~min}$ ), while in Q2 and Q3 the wetting phase was notably longer than the advance phase

249 (mean advance time in Q2 and Q3 was 6 and $12 \mathrm{~min}$, respectively). Mean applied water was 77,

250126 and $167 \mathrm{~mm}$ in Q1, Q2 and Q3, respectively. Therefore, the supply capacity of the typical

251 CPIS farm outlet (86 mm; see section 3.1) could meet the water requirement under strategy Q1

252 even with the entire area (2 ha) under irrigation; strategy Q3 would be feasible if not more than

253 half of the area was irrigated; and strategy Q2 would be feasible with up to two thirds of the

254 area under irrigation.

255 After a certain wetting time, infiltration was stabilized and the outflow rate reached a constant

256 value for each furrow. The difference between the stabilized inflow and outflow rates allowed

257 the calculation of the basic infiltration rate for each furrow monitored. This rate varied greatly

258 between sites and from furrow to furrow (Fig. 7). It showed some correlation with the inflow

259 rate for each treatment; however, the relationship was different between treatments. This

260 striking behaviour was observed in both sites and was not related to a decrease in the basic

261 infiltration rate as the number of irrigation events accumulates throughout the season, as other

262 authors have observed (Mateos and Oyonarte, 2005).

\subsection{Soil loss vs. irrigation performance}

264 The treatments had a clear effect on soil loss. Figure 8 depicts soil loss accumulated during the

2655 and 4 irrigation events monitored in Site 1 and Site 2, respectively. The largest soil loss,

266 observed in Site 2 under treatment Q3, was $2.8 \mathrm{Mg} \mathrm{ha}^{-1}$ in 4 irrigation events. Soil loss in Site 1

267 (sandy loam) was, on average, lesser than in Site 2 (silty clay loam) for all treatments despite 
the former receiving one more irrigation and being slightly steeper. However, soil loss variability in Site 2 was much greater than in Site 1. Furrow 1 of treatment Q2 and furrow 3 of treatment Q3 yielded anomalously large soil losses in all irrigation events in Site 2.

Figure 9 depicts soil loss $v s$. distribution uniformity and application efficiency computed for each furrow monitored, showing a wide variety of situations. In both sites, maximum $D U$ was around $95 \%$, while minimum $D U$ was around $70 \%$, the lowest values occurring under Q1 and the highest under Q2 (Site 2) or Q3 (Site 1). Soil loss tended to increase with $D U$, although the correlation was weak in Site 2 (Fig. 9). Q1, the treatment that clearly yielded less soil loss, had a mean $D U$ of about $81 \%$, against a mean $D U$ of $90 \%$ in Q2 and Q3. The maximum $D U$ under Q2 (not under Q3) in Site 2 was unexpected. Thorough examination of the data revealed that this was due to the low basic infiltration rate observed in several irrigation events on block Q2 (particularly irrigations I and II). This also contributed to the high soil loss observed in furrow 1 under Q2: the low infiltration rate obliged to a long wetting phase (to meet the target infiltrated depth), which, in turn, implied a large soil loss. Soil heterogeneity was therefore the cause of the large scatter observed in Fig. 9, which was greatest in Site 2. Furthermore, the infiltrated depth used to compute $D U$ varied along the furrow with opportunity time only, that is, the infiltration variability due to the heterogeneity of soil infiltration characteristics was not taken into account. $D U$ was therefore an upper limit of actual infiltration uniformity.

Mean $E_{a}$ in Site 1 was 53, 41 and $39 \%$ under Q1, Q2, and Q3, respectively, although scatter was also considerable (Fig. 9a), to the point that the two highest values of $E_{a}$ were observed in Q2 and Q3. In Site 2, the scatter was even greater than in Site 1 (Fig. 9b). Mean $E_{a}$ in Site 2 was 47, 32 and $47 \%$ under Q1, Q2, and Q3, respectively. Highest $E_{a}$ corresponded to relatively low TWR (less than $35 \%$ ) (Fig. 10ab) and relatively high DPR (DPR was generally less than $20 \%$, data not shown) in both Sites. Conversely, the lowest $E_{a}$ corresponded to furrow irrigation events with high $T W R$ despite $D P R$ being low. Globally, a large soil loss was associated with high $D U$, low $E_{a}$, high $T W R$, and low $D P R$, conditions more typical of Q2 and Q3 than of Q1. Although $D U$ in Q1, the treatment that conserved most soil, was lesser than in Q2 and Q3, nonuniformity could not affect crop growth (remember that the irrigation strategy imposed $E_{r}=100$ $\%)$.

\section{Discussion}

Smallholder farmers, over the years, have acquired furrow irrigation experience, an inexpensive way of watering crops. However, potential performance of furrow irrigation has inherent limitations. Furrow infiltration variability is usually estimated based only on the variation of the 
infiltration opportunity time along the furrow (Walker and Skogerboe, 1987). However, this source of variability is likely to be a minor one compared with that due to inflow rate variability (Trout, 1990) or to soil heterogeneity, particularly where the furrows are short and the advance time is a small fraction of the application time, as happens in CPIS. In our experiments, advance time varied from about $10 \mathrm{~min}(\mathrm{Q} 1)$ to about $50 \mathrm{~min}(\mathrm{Q} 3)$, with application times varying from approximately $50 \mathrm{~min}$ to $90 \mathrm{~min}$, respectively. With advance and application times of this order of magnitude, Childs et al. (1993) found that on considering the soil infiltration characteristics to be variable and the opportunity time to be constant, the coefficient of variation of the infiltrated depth was between 1.5 and 5 times greater than when considering the soil to be homogeneous and the opportunity time variable. Similarly, Oyonarte et al. (2002) found that soil infiltration characteristics accounted for $45-71 \%$ of the variance of infiltrated depth under first irrigation conditions, and for more than $76 \%$ in subsequent irrigations. In addition, Boulal et al. (2011ab) observed that infiltration is very much affected by soil management. The variability among furrows of the basic infiltration rate exhibited in Figure 7 is an additional source of infiltration variability across the field that superimposes the in-furrow variability. Moreover, Figure 7 shows another unexpected source of infiltration non-uniformity across the field: the correlation between $f_{o}$ and $Q_{i n}$ was different for the different ranges of $Q_{i n}$ tested there. This phenomenon could be due to a neighbourhood effect: what distinguishes one furrow with a given flow rate in one treatment from furrows with the same or similar flow rate in another treatment is that each of them are flanked by furrows with flow rates of a different magnitude. The possible neighbourhood effect would be probably related to differences in the wetted perimeter, another factor that influences furrow infiltration (Izadi and Wallender, 1985; Oyonarte et al., 2002). Another possible cause of this phenomenon could be erosion itself, which could cause surface sealing at high inflow rates (Trout and Mackey, 1988). The corollary is that when soil characteristics that affect infiltration variability are taken into account, furrow irrigation performance is significantly poorer than when, like in the standard evaluation procedure, they are ignored.

The trade-offs between distribution uniformity and application efficiency (Fig. 9) and between the tail water and deep percolation ratios (Fig. 10) entail nutrient leaching, on one hand, and runoff, soil loss and surface water pollution, on the other. Runoff seemed to be a major cause of inefficiency and of environmental damage caused by furrow irrigation. The mean soil loss accumulated during the 5 and 4 irrigation events monitored in Sites 1 and 2, respectively, ranged between 0.25 and $2.80 \mathrm{Mg} \mathrm{ha}^{-1}$ (Fig. 8). Considering that the typical number of irrigations would be about twice the number of irrigations monitored, the annual irrigationinduced soil losses in the Q3 treatment would be below the soil loss tolerance of $12 \mathrm{Mg} \mathrm{ha}^{-1} \mathrm{y}^{-1}$ established by the USDA Natural Resources Conservation Service (1999) for this kind of soil. 
However, this threshold is only based on soil productivity and soil formation rate, ignoring the off-site effects of soil erosion (Li et al., 2009). Therefore, irrigation on the soils of CPIS must be carefully managed given their susceptibility to erosion, especially the sandy loam soils.

341 Treatment Q1 could represent the best compromise between irrigation performance indicators 342 and soil loss. In spite of that, the environmental impact associated with irrigation runoff and 343 deep percolation deduced from Figures 9 and 10, and aggravated by poor drainage, questions 344 the sustainability of current irrigation practices in CPIS (Alburquerque et al., 2018). Furrow irrigation could be improved in CPIS by using small-diameter syphons and carrying out cutback

346 flow. An irrigation advisory service could easily promote those syphons. Cutback flow would 347 alter current practices, so it would require some effort from the advisors, but it could be an easy 348 and effective method to reduce both deep percolation and runoff (Gudissa and Edossa, 2014). In 349 CPIS, the cutback method could be implemented by placing two small-diameter siphons at the head of each furrow, for rapid water advance, and then removing one of them, to complete irrigation with a reduced outflow rate (Kay, 1986). Other measures to improve furrow irrigation performance could be blocked-end furrows (where feasible), laser levelling (although its cost per area in smallholdings could be significant) and reusing runoff water (which would require new infrastructures such us regulation reservoirs and pumps).

355 Furrow irrigation performance in CPIS is not encouraging and suffers from the same 356 predicament as other irrigation technologies elsewhere. The performance of furrow irrigation in 357 CPIS is no better than that of micro irrigation in the nearby Baixo Acaraú irrigation district 358 (Mateos et al., 2018). Poor performance or success of modern irrigation systems such as drip 359 irrigation (Wanvocke et al., 2015; Venot et al., 2018) could be better contextualized if compared 360 with that of traditional surface methods. Although the soils allocated for irrigation in CPIS are good alluvial ones, suitable for surface irrigation, experiments carried out in the district showed that drip irrigation was able to increase pumpkin yield significantly using considerably less water than furrow irrigation (Santos et al., 2010). However, irrigation performance has to be related to the technological context, to the actual irrigation practices, and to the farmer's decision-making process (Benouniche et al., 2014a). An open innovation environment may favour the adoption of good irrigation practices, the adaptation of modern technology to local needs (Poncet et al., 2010; Benouniche et al., 2014b), and the "technology translation" flow

368 (Garb and Friedlander, 2014). Improved irrigation practices can be envisaged even for 369 traditional surface irrigation. For instance, the cutback flow could be adopted in CPIS through local adaptation. However, the evidence has shown that this has not happened yet. The Brazilian government constructed CPIS in the 1970s to improve the livelihood of farmers who did not have any previous irrigation experience. Farming was supported with well-trained engineers and 
agronomy advisors. Unfortunately, the government withdrew this support during the 1980 s, so farmers lost their capacity to adopt good irrigation practices and to innovate.

Collective irrigation schemes are normally designed and managed for specific on-farm irrigation methods, i.e. surface irrigation in CPIS. In turn, Gonçalves et al. (2015) attributed the poor performance of CPIS to the on-farm irrigation method. Moreover, the delivery and maintenance service initially provided by CPIS was drastically reduced in the 1980s. Insufficient maintenance and deficient operation usually trigger the degradation spiral that has been described for other irrigation schemes in developing countries (Garcia-Bolaños et al., 2011; Borgia et al., 2013). On the other hand, transforming a collective gravity system into a pressurized one, for micro or sprinkler irrigation, may not be successful, is expensive, and precludes surface irrigation. Furthermore, the improvement of global (irrigation and environmental) efficiency would be largely affected by the hydrological setting and layout of the irrigation scheme (Mateos, 2008). Therefore, when dealing with collective irrigation schemes, the debate about which irrigation method best fits smallholder's needs has to go beyond the farm context. Alternative approaches allowing the coexistence of on-farm gravity and pressurized irrigation would satisfy a diversity of smallholder needs and farming strategies and would favour more open innovation. Modern decision support systems would then become essential management tools (Lozano and Mateos, 2008).

\section{Conclusions}

Furrow irrigation is a low-cost technology that smallholders can afford. The cost of the equipment necessary to irrigate 2-ha blocks in CPIS with the typical flow rate of $2.4 \mathrm{~m}^{3} \mathrm{~min}^{-1}$ at the farm outlets is about US\$ 300 (syphons plus hoes). Moreover, once the irrigator has acquired some practice, furrow irrigation is relatively easy to operate compared to modern micro irrigation systems. However, furrow irrigation poses some important environmental problems; runoff in the experimental sites represented up to $70 \%$ of the applied water (ranged from 20 to $70 \%$ ). This runoff was able to carry sediment loads of up to $5.6 \mathrm{Mg} \mathrm{ha}^{-1}$ in an irrigation season on Site 2 (silty clay loam soil with slope of $0.32 \%$ ).

Irrigation performance and soil loss notably varied in the experiments, so we assumed that the range of variation observed covered what can be found in CPIS. There were no performances that could be described as good. Notwithstanding, we could suggest simple practices (e.g., reducing the size of the syphon or carrying out cutback flow) that could significantly improve furrow irrigation performance in CPIS. We contend that, with public support, irrigation advisory services (Córcoles et al., 2016) could help to introduce such practices. 
While recent studies have questioned both the potential of drip irrigation to save water and its adaptability to smallholders' needs, our study shows serious environmental problems that are in practice inherent to traditional surface irrigation. This conclusion contributes to the debate about the adoption and performance of new irrigation technology on smallholdings of developing regions and about the transformation of collective gravity systems into pressurized ones.

\section{Acknowledgements}

The contribution of L. Mateos was partially funded by the project "Bases Científicas do Assessoramento na Melhoria da Irrigação", Programa Ciência Sem Fronteiras, 61/2011 MEC/MCTI/CAPES/CNPQ/FAPs, Brazil.

\section{References}

Abramowitz, M., Stegun, I. A., 1972. Handbook of Mathematical Functions with Formulas, Graphs, and Mathematical Tables, 9th printing. New York: Dover, p. 885.

Albuquerque, J.A., Costa, R.N.T., Ribeiro, R.S.F., Gheyi, H.R., 2018. Responsabilidade objetiva na geração de passivo ambiental pela irrigação. Irriga 23, 402-412.

ANA, Agência Nacional de Águas, 2017. Atlas irrigação: uso da água na agricultura irrigada. Agência Nacional de Águas, Brasília, Brazil, 86 pp.

Bautista, E., Wallender, WW., 1985. Spatial variability of infiltration in furrows. Transactions of the ASAE 28,1846-1851,1855.

Bautista, E., Clemmens, A.J., Strelkoff, T.S., Schlegel, J., 2009. Modern analysis of surface irrigation systems with WinSRFR. Agricultural Water Management 96, 1146-1154.

Beck, H.E., Zimmermann, N.E., McVicar, T.R., Vergopolan, N., Berg, A., Wood, E.F., 2018. Present and future Köppen-Geiger climate classification maps at 1-km resolution. Nature Scientific Data 5, 180214

Benouniche, M., Kuper, K., Hammani, A., 2014a. Making the user visible: analysing irrigation practices and farmers' logic to explain actual drip irrigation performance. Irrigation Science 32, 405-420.

Benouniche, M., Zwarteveen, M., Kuper, M., 2014b. Bricolage as innovation: opening the black box of drip irrigation systems. Irrigation and Drainage, 63: 651-658. 
Borgia, C., García-Bolaños, M., Li, L., Gómez-Macpherson, H., Comas, J., Connor, D., Mateos, L., 2013. Benchmarking for performance assessment of small and large irrigation schemes along the Senegal Valley in Mauritania. Agricultural Water Management 121, 19-26

Boulal, H., Gómez-Macpherson, H., Gómez, J.A., Mateos, L., 2011a. Effect of soil management and traffic on soil erosion in irrigated annual crops. Soil and Tillage Research 115-116, 62-70

Boulal, H., Mateos, L., Gómez-Macpherson, H., 2011b. Soil management and traffic effects on infiltration of irrigation water applied using sprinklers. Irrigation Science 29, 403-412 2014. Climate change adaptation strategies for smallholder farmers in the Brasilian Sertão.

446 Climatic Change 126, 45-59.

447 Burney, J.A., Naylor, R.L., Postel, S.L., 2013. The case for distributed irrigation as a 448 development priority in sub-Saharan Africa. PNAS 110, 12513-12517.

449 Burt, C.M., Clemmens, A.J., Strelkoff, T.S., Solomon, K.H., Bliesner, R.D., Hardy, L.A., 450 Howell, T.A., Eisenhauer, D.E., 1997. Irrigation performance measures: efficiency and 451 uniformity. Journal of Irrigation and Drainage Engineering 123, 423-442

Childs, J. L., Wallender, W. W., Hopmans, J. W., 1993. Spatial and seasonal variation of furrow irrigation. Journal of Irrigation and Drainage Engineering 119, 74-90.

454 Comas, J., Connor, D., Isselmou, M., Mateos, L., Gómez-Macpherson, H., 2012. Why has 455 small-scale irrigation not responded to expectations with traditional subsistence farmers along 456 the Senegal River in Mauritania? Agricultural Systems 110, 152-161

457 Connor, D.J., J. Comas, H. Gomez-Macpherson and L. Mateos. 2008. Impact of smallholder 458 irrigation on agricultural production, food supply and economic prosperity of a representative 459 village beside the Senegal River, Mauritania. Agricultural Systems 96, 1-15

460 Corcoles, J.I., Frizzone, J.A., Lima, S.C.R.V., Mateos, L., Neale, C.M.U, Snyder, R.L., Souza, 461 F., 2016. Irrigation advisory service and performance indicators in Baixo Acaraú irrigation 462 district, Brazil. Irrigation and Drainage 65, 61-72.

463 FAO, 2006. World reference base for soil resources. World Soil Resources Reports No. 103. 464 FAO, Rome. 128 pp.

465 FAO. 2016. AQUASTAT website. Food and Agriculture Organization of the United Nations 466 (FAO). Website http://www.fao.org/nr/water/aquastat/main/index.stm accessed on 2018/02/15 
467 Fernández-Gómez R., Mateos L., Giráldez J.V., 2004. Furrow irrigation erosion and

468 management. Irrigation Science 23, 123-131.

469 Garb, Y., Friedlander, G., 2014. From transfer to translation: Using systemic understandings of

470 technology to understand drip irrigation uptake. Agricultural Systems 128, 13-24.

471 García-Bolaños, M., Borgia, C., Poblador, N., Dia, M., Seyid, O. M. V., Mateos, L., 2011.

472 Performance assessment of small irrigation schemes along the Mauritanian banks of the Senegal

473 River Agricultural Water Management 98, 1141-1152

474 Gonçalves, F.M., Ribeiro, R.S.F., Costa, R.N.T., Burte, J.D., 2015. A management analysis tool

475 for emancipated public irrigation areas using neural networks. Water Resources Management

476 29, 2393-2406.

477 Graeub, B.E., Chappell, M.J., Wittman, H., Ledermann, S., Kerr, R.B., Gemmill-Herren, B.

478 2016. The State of Family Farms in the World.World Development 87, 1-15.

479 Gudissa, H. D., Edossa, D.C., 2014. Evaluation of surge and cutback flow furrow irrigation

480 systems for pepper (Capsicum annuum) production. Irrigation and Drainage 63, 463-473

481 Hanjra, M.A., Ferede, T., Gutta, D.G., 2009. Reducing poverty in sub-Saharan Africa through

482 investments in water and other priorities. Agricultural Water Management 96, 1062-1070.

483 Hussain, I., 2007. Poverty-reducing impacts of irrigation: evidence and lessons. Irrigation and

484 Drainage 56, 179-194.

485 Hussain, I., Hanjra, M.A., 2004. Irrigation and poverty alleviation: review of the empirical

486 evidence. Irrigation and Drainage 53, 1-15.

487 INMET, 2018. Instituto Nacional de Meteorologia. http://www.inmet.gov.br/portal/ Accessed in 488 October 2018.

489 Izadi, B., Wallender, W. W., 1985. Furrow hydraulic characteristics and infiltration.

490 Transactions of the ASAE 28, 1901-1908.

491 Kay, M. 1986. Surface Irrigation Systems and Practice. Cranfield Press Cranfield Bedford, UK.

$492142 \mathrm{pp}$.

493 King, B.A., Bjorneberg, D.L., Trout, T.J., Mateos, L., Araujo, D.F., Costa, R.N., 2016.

494 Estimation of furrow irrigation sediment loss using an artificial neural network. Journal of

495 Irrigation and Drainage Engineering 142, 04015031.

496 Li, L, Du, S, Wu, L, Liu, G., 1987. An overview of soil loss tolerance. Catena 78, 93-99. 
Lowder, S.K., Skoet, J., Raney, T. 2016. The number, size, and distribution of farms, smallholder farms, and family farms worldwide. World Development 87, 16-29. Lozano, D., Mateos, L., 2008. Usefulness and limitations of decision support systems for improving irrigation scheme management. Agricultural Water Management 95, 409-418. Mateos, L., 2006. A simulation study of comparison of the evaluation procedures for three irrigation methods. Irrigation Science 25, 75-83.

Mateos, L. Giráldez, J.V., 2005. Suspended load and bed load in irrigation furrows. Catena 64, 232-246.

Mateos, L., Oyonarte, N.A., 2005. A spread sheet model to evaluate sloping furrow irrigation accounting for infiltration variability. Agricultural Water Management 76, 62-75.

507

Mateos, L., 2008. Identifying a new paradigm for irrigation system performance. Irrigation Science 27, 25-34. smallholder irrigation based on an energy-water-yield nexus approach. Agricultural Water Management 206, 176-186.

512 Oyonarte, N.A. Mateos, L., 2002. Accounting for soil variability in the evaluation of furrow 513 irrigation. Transactions of the ASAE 45, 85-94.

514 Oyonarte, N.A., Mateos, L., Palomo, M.J., 2002. Infiltration variability in furrow irrigation. 515 Journal of Irrigation and Drainage Engineering 128, 26-33.

516 Poncet, J., Kuper, M., Chiche, J., 2010. Wandering off the paths of planned innovation: The role 517 of formal and informal intermediaries in large-scale irrigation scheme in Morocco. Agricultural 518 Systems 103, 171-179.

519 Postel, S., Polak, P., Gonzales, F., Keller, J., 2001. Drip irrigation for small farmers: A new 520 initiative to alleviate hunger and poverty. Water International 26, 3-13.

521 Santos, M.D.S., Branco, L.M.C., Costa, R.N.T., Moreira, M.C., Macedo, A.B.M., 2010.

522 Eficiência de uso da água na cultura da abóbora em sistemas de irrigação por gotejamento e 523 sulcos. IX Congreso Latinoamericano y del Caribe de Ingeniería Agrícola - CLIA 2010 and 524 XXXIX Congresso Brasileiro de Engenharia Agrícola - CONBEA 2010. Vitória, Brazil, 25 525 Julyo 2010. 
526 Strelkoff, T.S., Clemmens, A.J., 2007. Hydraulics of Surface Systems. In: (G.J. Hoffman, R.G.

527 Evans, M.E. Jensen, D.L. Martin, R.L. Elliot, eds.) Design and Operation of Farm Irrigation

528 Systems. American Society of Agricultural and Biological Engineers St. Joseph, MI, US. P436-

529498.

530 Trout, T.J., 1996 Furrow irrigation erosion and sedimentation: on field distribution.

531 Transactions of the ASAE 39, 1717-1723.

532 Trout, T. J., 1990. Furrow inflow and infiltration variability impacts on irrigation management.

533 Transactions of the ASAE 33, 1171-1178.

534 Trout, T. J., Mackey, B. E., 1988. Furrow inflow and infiltration variability. Transactions of the 535 ASAE 31, 531-537.

536 Trout, T.J., Neibling, W.H., 1993 Erosion and sedimentation processes on irrigated fields.

537 Journal of Irrigation and Drainage Engineering 119, 947-963.

538 USBR, 1997. Water Measurement Manual. Chapter 8 - FLUMES, Section 10 - Parshall Flumes.

539 US Bureau of Reclamation. $3^{\text {rd }}$ Edition. Denver, CO.

540 USDA/NRCS (United States Department of Agriculture/Natural Resources Conservation

541 Service) (1999). National soil survey handbook, title 430-VI. Available online at

542 http://soils.usda.gov/technical/handbook/. Accessed 12/29/2014.

543 Venot, J-P., Kuper, M., Zwarteveen, M. (eds.), 2018. Drip Irrigation for Agriculture. Untold

544 Stories of Efficiency, innovation and Development. Routledge, Taylor \& Francis Group. 358

545 pp.

546 Walker, W.R., Skogerboe, G.V., 1987. Surface Irrigation. Theory and Practice. Prentice-Hall

547 Inc., Englewood Cliffs, New Jersey, p. 386.

548 Wanvoeke, J. Venot, J-P, Zwarteveen, M., de Fraiture, C., 2015. Performing the success of an 549 innovation: the case of smallholder drip irrigation in Burkina Faso. Water International 40, 432550445. 
554 Table 1. Soil characteristics $(0-30 \mathrm{~cm})$ in the two experimental sites.

\begin{tabular}{lcc}
\hline & Site 1 (sandy loam) & Site 2 (silty clay loam) \\
\hline Sand (\%) & 72 & 14 \\
Silt (\%) & 19 & 56 \\
Clay (\%) & 9 & 30 \\
Bulk density $\left(\mathrm{kg} \mathrm{m}^{-3}\right)$ & 1360 & 1340 \\
Electrical conductivity $\left(\mathrm{dS} \mathrm{m}^{-1}\right)$ & 0.49 & 1.77 \\
$\mathrm{pH}$ & 6.7 & 7.7 \\
Organic matter $\left(\mathrm{g} \mathrm{kg}^{-1}\right)$ & 20 & 27 \\
\hline
\end{tabular}

555

556

\section{$557 \quad$ Figures caption}

558 Figure 1. Location maps in Brazil

559 Figure 2. Sketch of the experimental areas indicating the location of treatments Q1, Q2 and Q3

560 (application of water with syphons with diameter 25.4, 38.1 and $50.8 \mathrm{~mm}$, respectively), the

561 location of the flumes, and the location of the secondary canal and drainage ditch

562 Figure 3. Example of furrow irrigation process on Site 1 (sandy loam), treatment Q1

563 (application of water with syphons with diameter of 25.4, mm), irrigation I. (a) Advance and

564 recession trajectories, (b) infiltration estimated along the furrow, and (c) inflow and outflow

565 hydrographs and sediment concentration in the runoff water.

566 Figure 4. Average bed elevation along the furrows in Sites 1 and 2 (sandy loam and silty clay

567 loam, respectively). The variability bars indicate plus and minus standard deviation.

568 Figure 5. Box plot chart representing the mean and variability of the inflow rated supplied by

569 the syphons of diameter $25.4 \mathrm{~mm}(\mathrm{Q} 1), 38.1 \mathrm{~mm}(\mathrm{Q} 2)$ and $50.8 \mathrm{~mm}(\mathrm{Q} 3)$.

570 Figure 6. Mean advance time for each inflow treatment and irrigation event in (a) Site 1 (sandy

571 loam) and (b) Site 2 (silty clay loam). The bars indicate plus-minus standard deviation among

572 replication furrows.

573 Figure 7. Basic infiltration rate for every furrow in each treatment represented against the

574 corresponding inflow rate, in (a) Site 1 (sandy loam) and (b) Site 2 (silty clay loam). 
575 Figure 8. Soil loss vs. treatment mean inflow rate in Sites 1 and 2 (sandy loam and silty clay

576 loam, respectively). The horizontal and vertical bars indicate plus-minus standard deviation

577 among replication furrows.

578 Figure 9. Sediment loss vs. Distribution Uniformity and Application Efficiency for all furrows

579 and irrigation events in treatments Q1, Q2 and Q3 (application of water with syphons with

580 diameter 25.4, 38.1 and $50.8 \mathrm{~mm}$, respectively) in (a) Site 1 (sandy loam) and (b) Site 2 (silty

581 clay loam).

582 Figure 10. Sediment loss vs. Tail Water Ratio for all furrows and irrigation events in treatments

583 Q1, Q2 and Q3 (application of water with syphons with diameter 25.4, 38.1 and $50.8 \mathrm{~mm}$,

584 respectively) in (a) Site 1 (sandy loam) and (b) Site 2 (silty clay loam).

585 


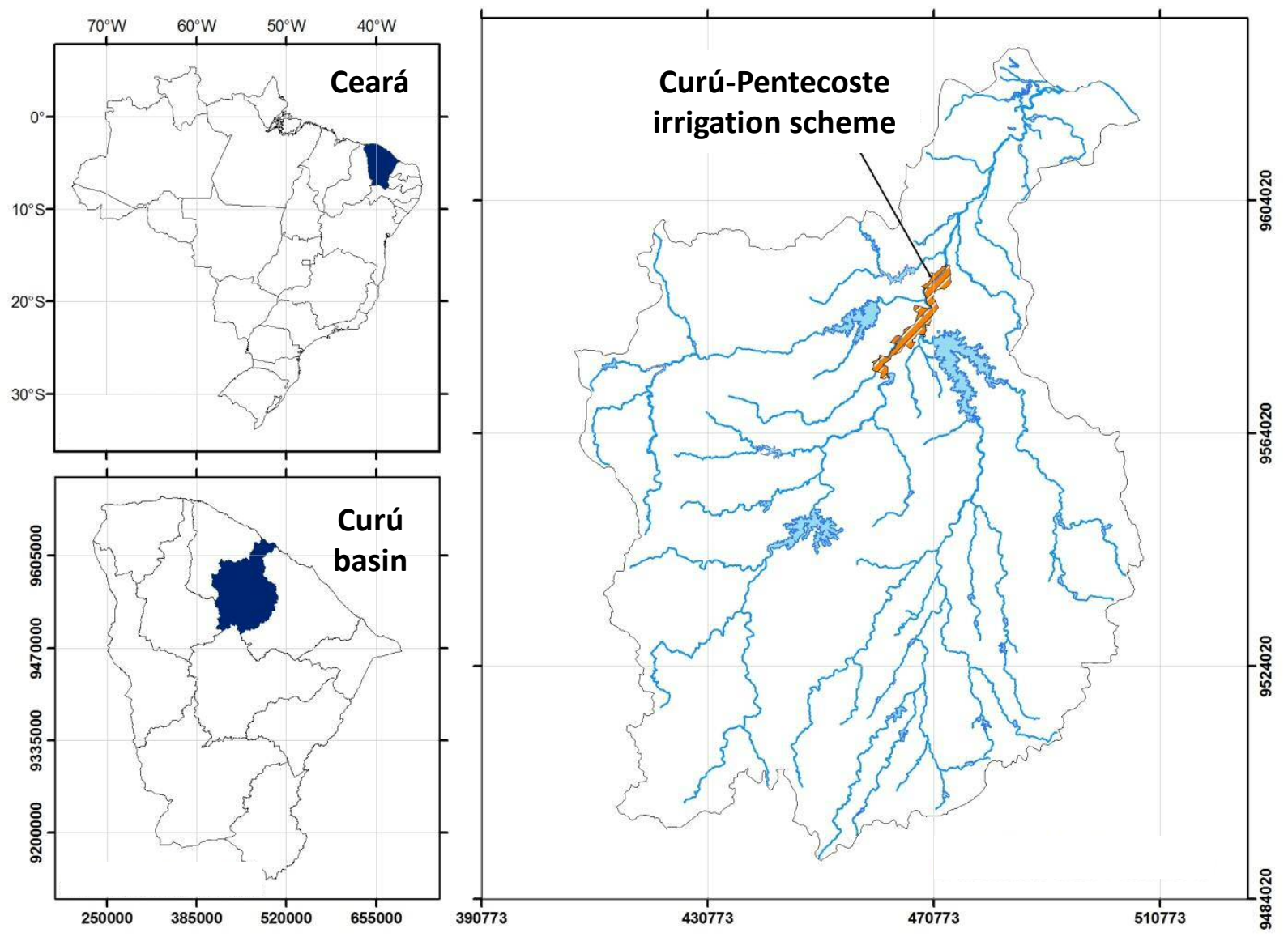

Figure 1 


\section{Secondary canal}

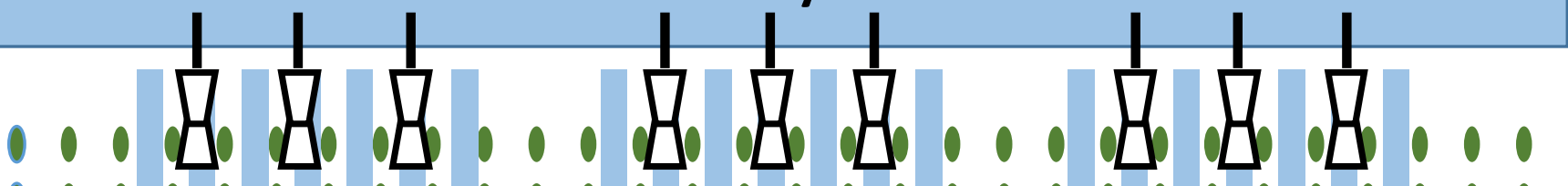

$\begin{array}{llllllllllllllllllllllllllllll}0 & 0 & 0 & 0 & 0 & 0 & 0 & 0 & 0 & 0 & 0 & 0 & 0 & 0 & 0 & 0 & 0 & 0 & 0 & 0 & 0 & 0 & 0 & 0 & 0 & 0 & 0 & 0 & 0 & 0\end{array}$ $\begin{array}{lllllllllllllllllllllllllllllll}1 & 0 & 0 & 0 & 0 & 0 & 0 & 0 & 0 & 0 & 0 & 0 & 0 & 0 & 0 & 0 & 0 & 0 & 0 & 0 & 0 & 0 & 0 & 0 & 0 & 0 & 0 & 0 & 0 & 0\end{array}$ $\begin{array}{lllllllllllllllllllllllllllllll}1 & 0 & 0 & 0 & 0 & 0 & 0 & 0 & 0 & 0 & 0 & 0 & 0 & 0 & 0 & 0 & 0 & 0 & 0 & 0 & 0 & 0 & 0 & 0 & 0 & 0 & 0 & 0 & 0 & 0\end{array}$ $\begin{array}{lllllllllllllllllllllllllllllll}1 & 0 & 0 & 0 & 0 & 0 & 0 & 0 & 0 & 0 & 0 & 0 & 0 & 0 & 0 & 0 & 0 & 0 & 0 & 0 & 0 & 0 & 0 & 0 & 0 & 0 & 0 & 0 & 0 & 0\end{array}$ $\begin{array}{lllllllllllllllllllllllllllllll}1 & 0 & 0 & 0 & 0 & 0 & 0 & 0 & 0 & 0 & 0 & 0 & 0 & 0 & 0 & 0 & 0 & 0 & 0 & 0 & 0 & 0 & 0 & 0 & 0 & 0 & 0 & 0 & 0 & 0\end{array}$ $\begin{array}{lllllllllllllllllllllllllllllll}0 & 0 & 0 & 0 & 0 & 0 & 0 & 0 & 0 & 0 & 0 & 0 & 0 & 0 & 0 & 0 & 0 & 0 & 0 & 0 & 0 & 0 & 0 & 0 & 0 & 0 & 0 & 0 & 0 & 0\end{array}$ $\begin{array}{lllllllllllllllllllllllllllllll}1 & 0 & 0 & 0 & 0 & 0 & 0 & 0 & 0 & 0 & 0 & 0 & 0 & 0 & 0 & 0 & 0 & 0 & 0 & 0 & 0 & 0 & 0 & 0 & 0 & 0 & 0 & 0 & 0 & 0\end{array}$ $\begin{array}{lllllllllllllllllllllllllllllll}0 & 0 & 0 & 0 & 0 & 0 & 0 & 0 & 0 & 0 & 0 & 0 & 0 & 0 & 0 & 0 & 0 & 0 & 0 & 0 & 0 & 0 & 0 & 0 & 0 & 0 & 0 & 0 & 0 & 0\end{array}$ $\begin{array}{lllllllllllllllllllllllllllllll}0 & 0 & 0 & 0 & 0 & 0 & 0 & 0 & 0 & 0 & 0 & 0 & 0 & 0 & 0 & 0 & 0 & 0 & 0 & 0 & 0 & 0 & 0 & 0 & 0 & 0 & 0 & 0 & 0 & 0\end{array}$ $\begin{array}{lllllllllllllllllllllllllllllll}0 & 0 & 0 & 0 & 0 & 0 & 0 & 0 & 0 & 0 & 0 & 0 & 0 & 0 & 0 & 0 & 0 & 0 & 0 & 0 & 0 & 0 & 0 & 0 & 0 & 0 & 0 & 0 & 0 & 0\end{array}$

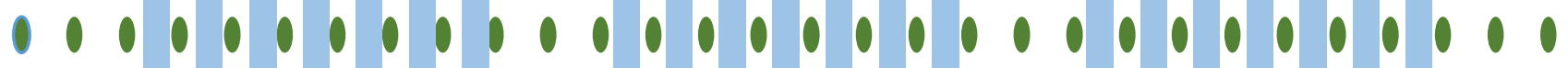

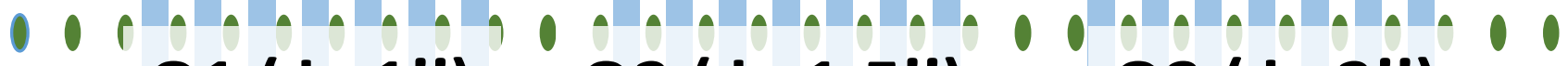
, Q1 ( $\left.\phi=1^{\prime \prime}\right), Q 2\left(\phi=1.5^{\prime \prime}\right)$

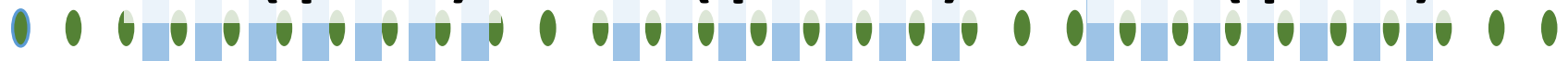

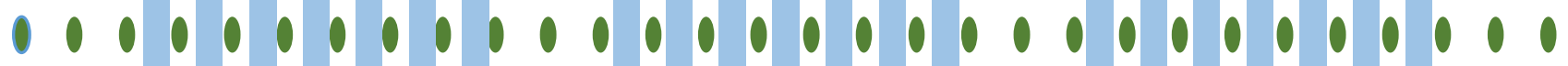

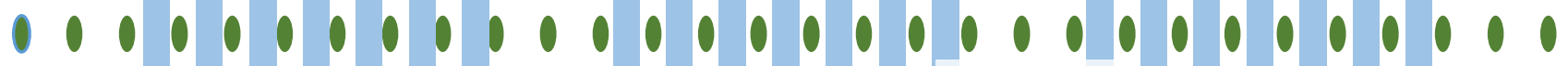

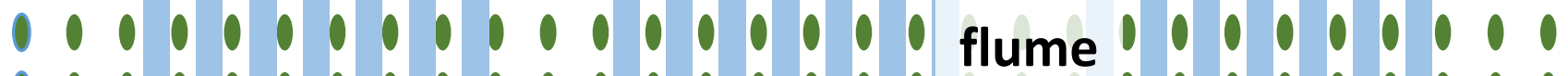

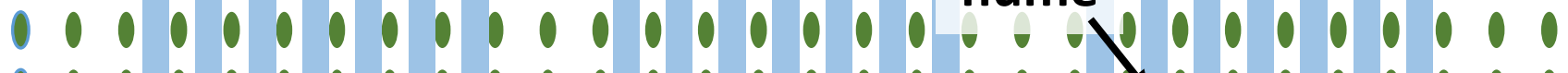
$\because \begin{array}{llll}1 & 0\end{array}$

\section{Drainage ditch}

Figure 2 

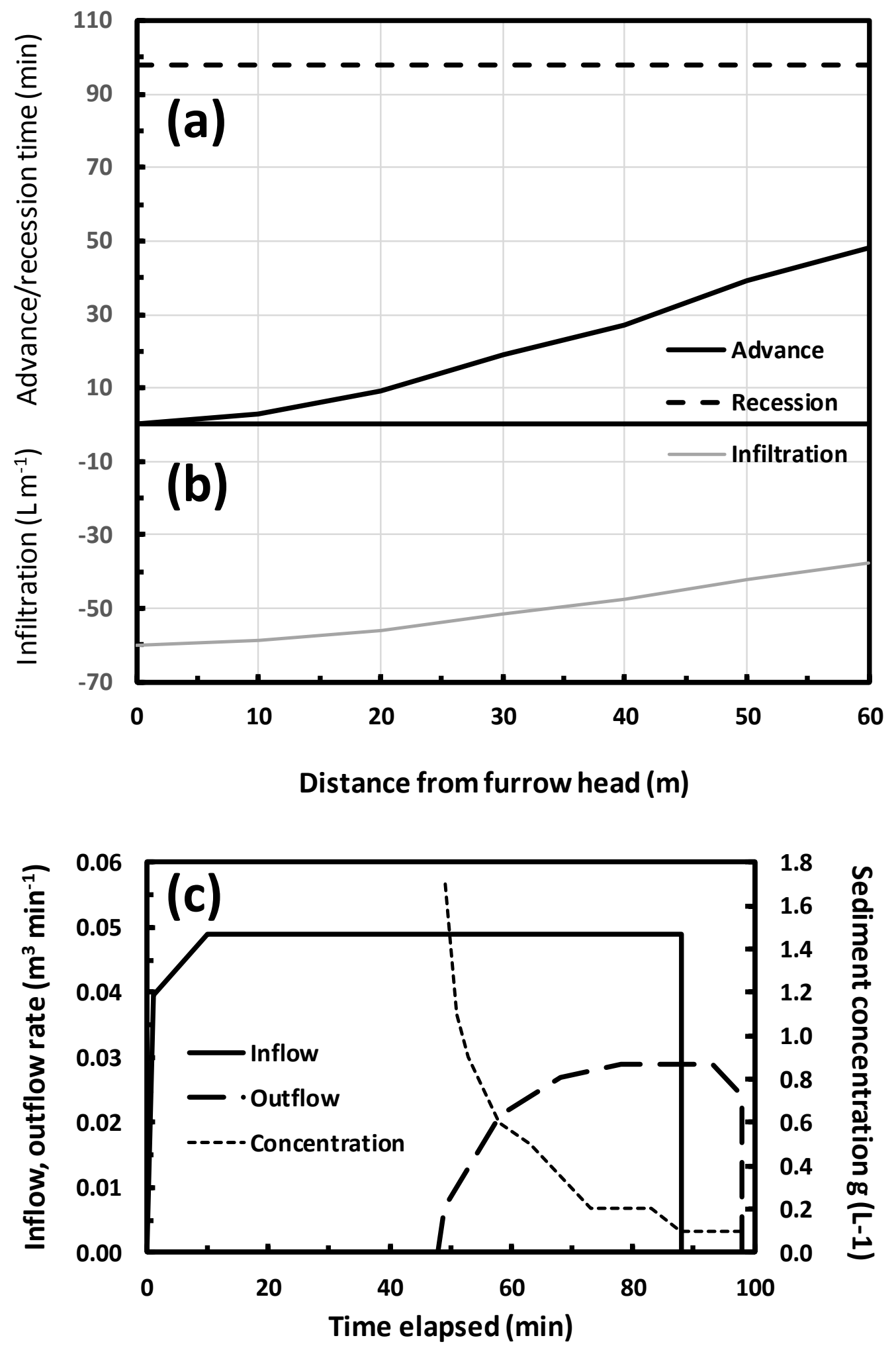

Figure 3 


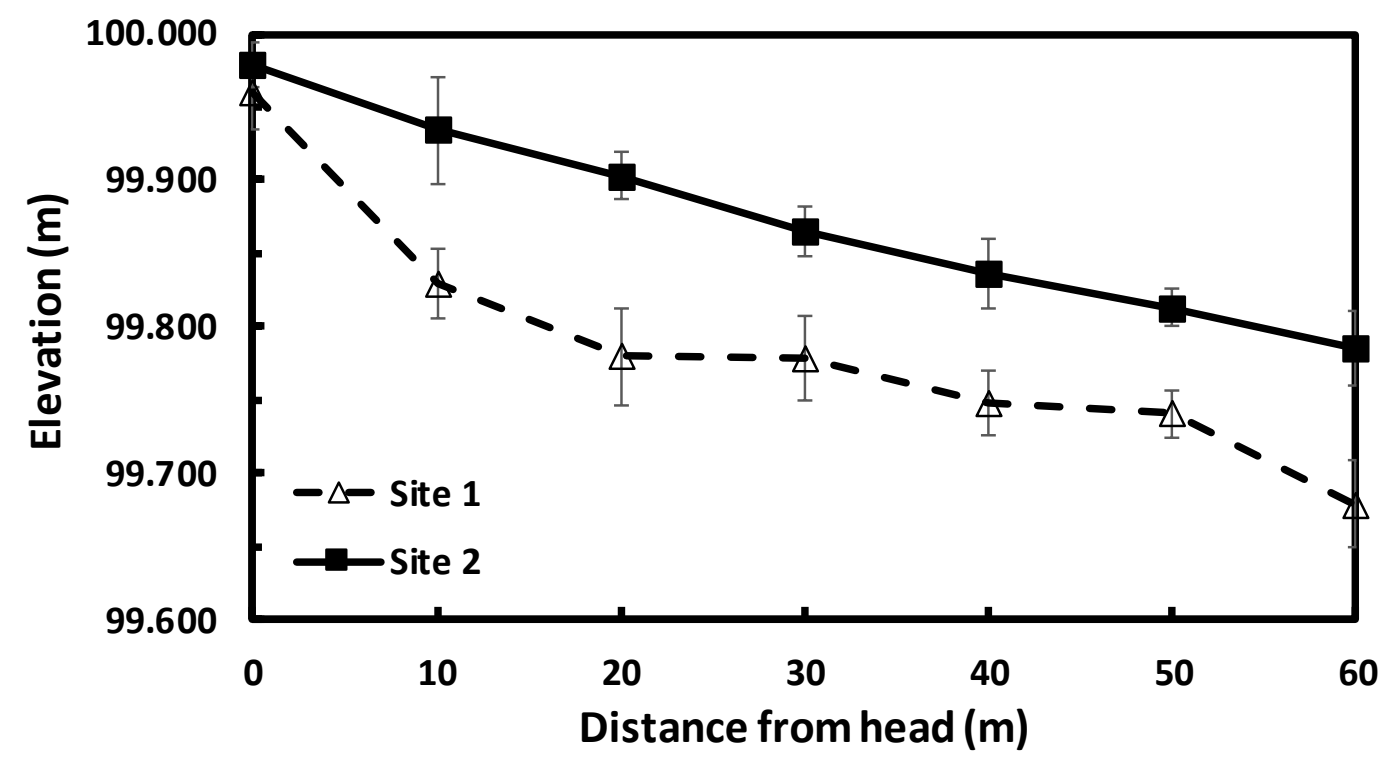

Figure 4 


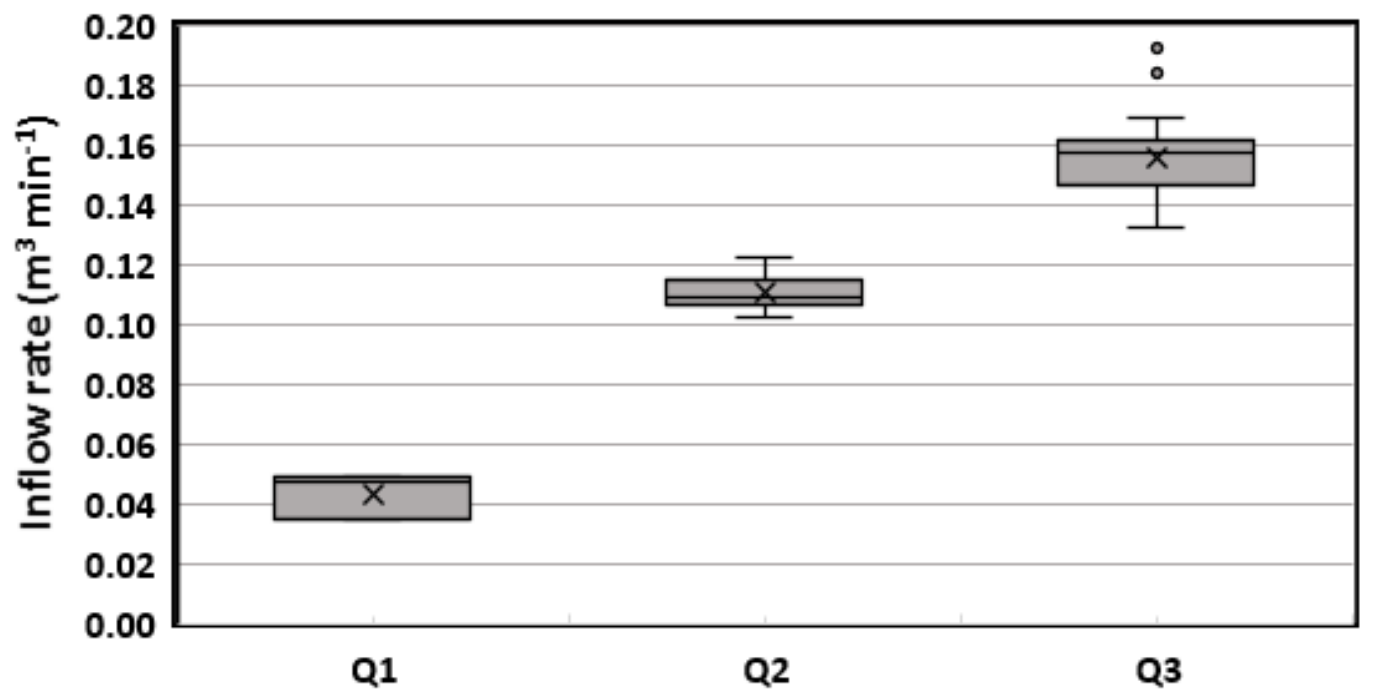

Figure 5 

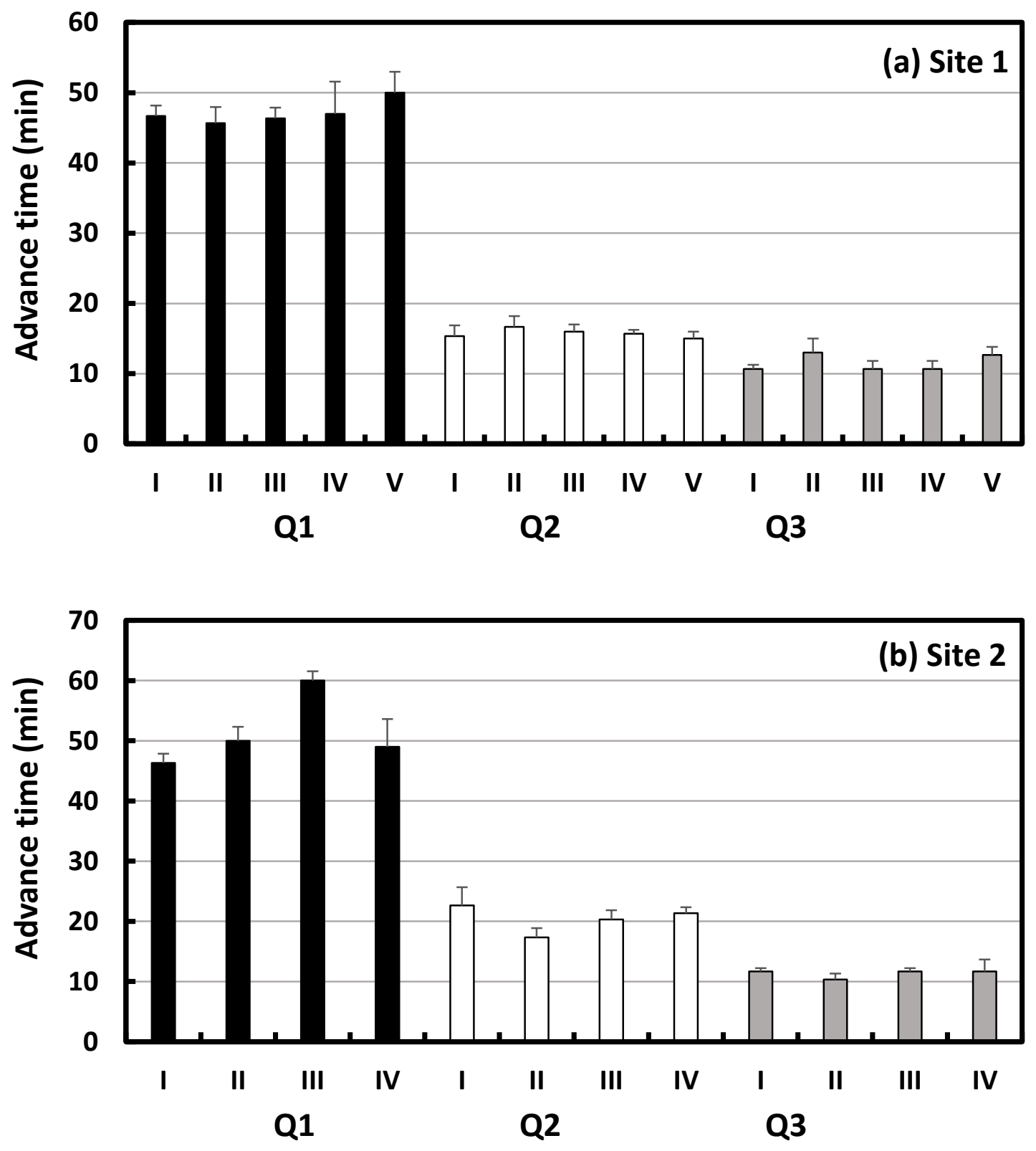

Figure 6 

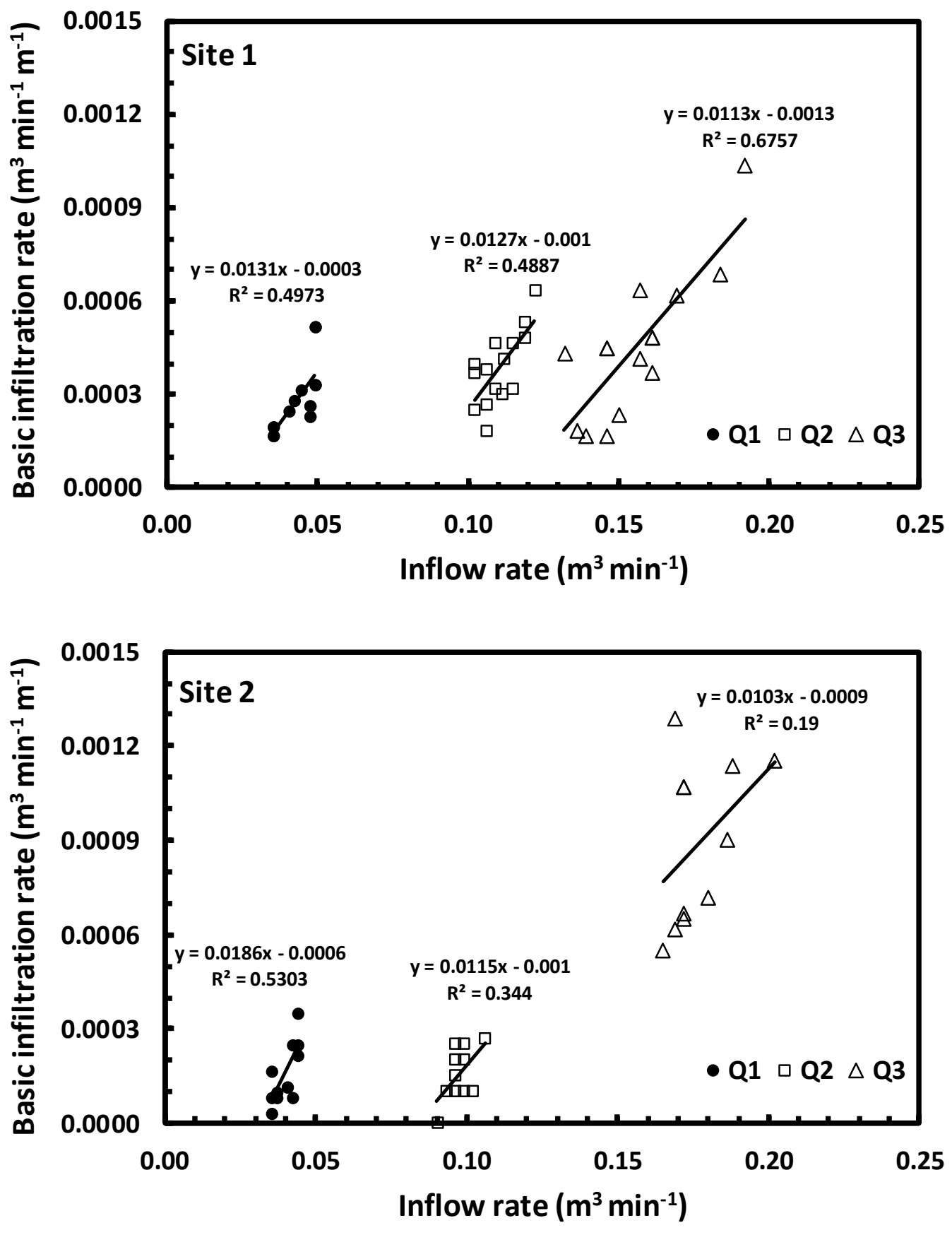

Figure 7 


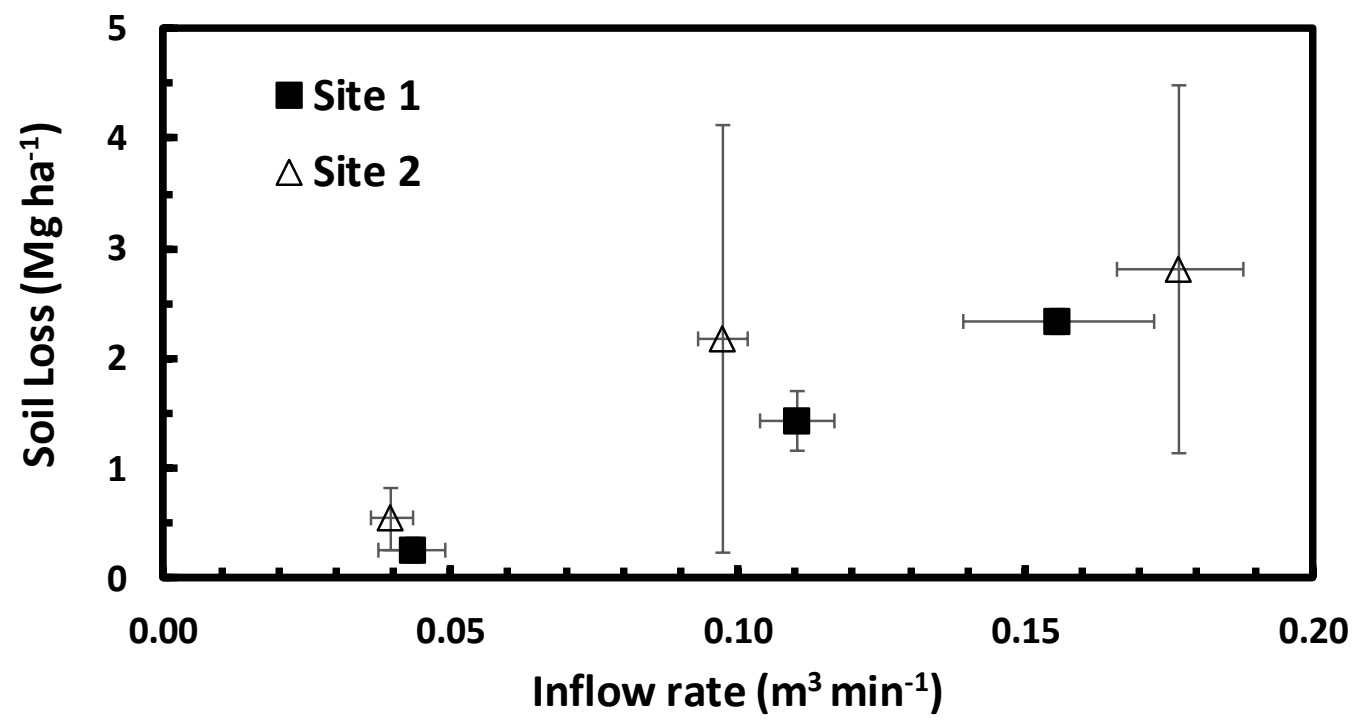

Figure 8 

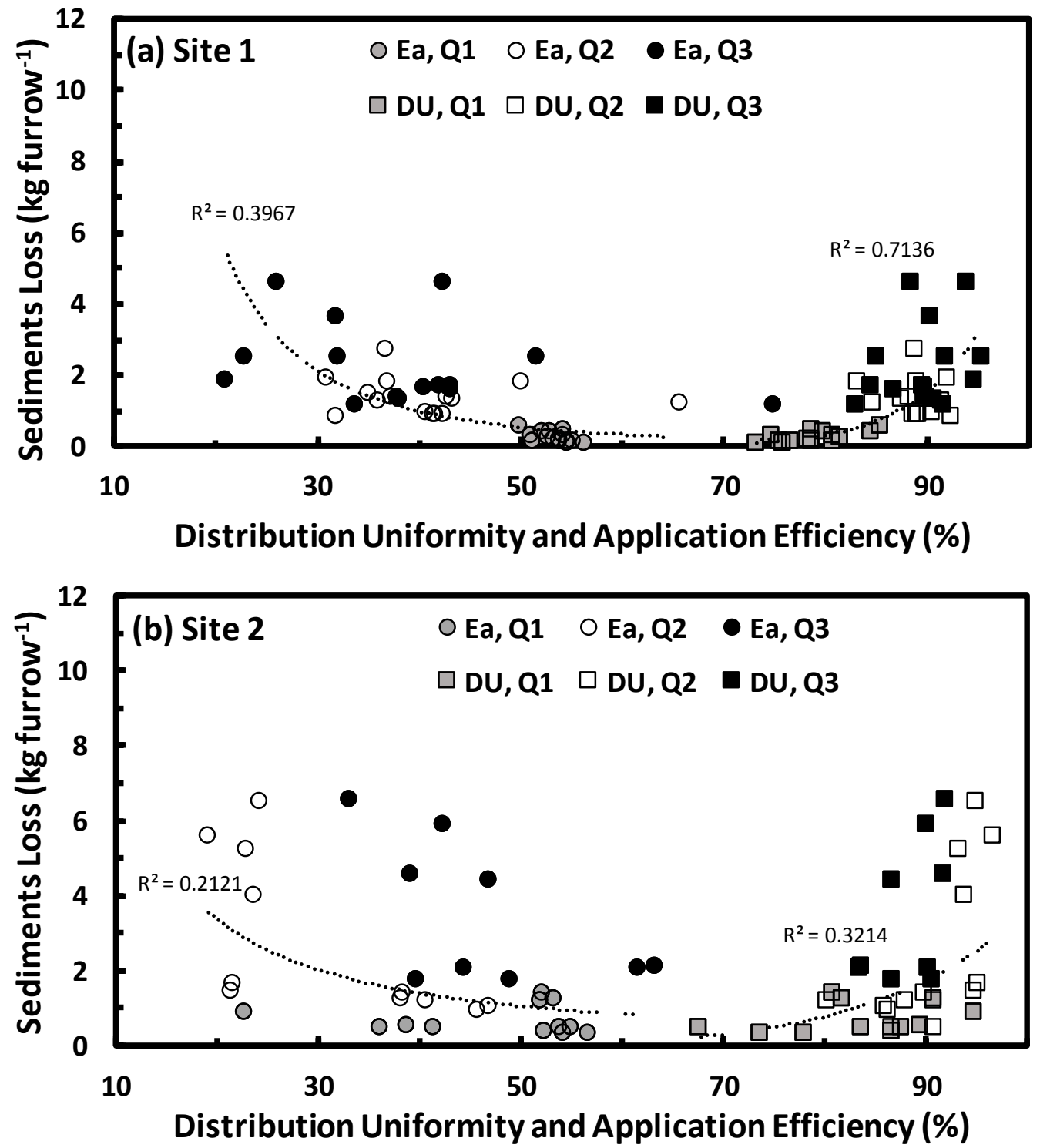

Figure 9 

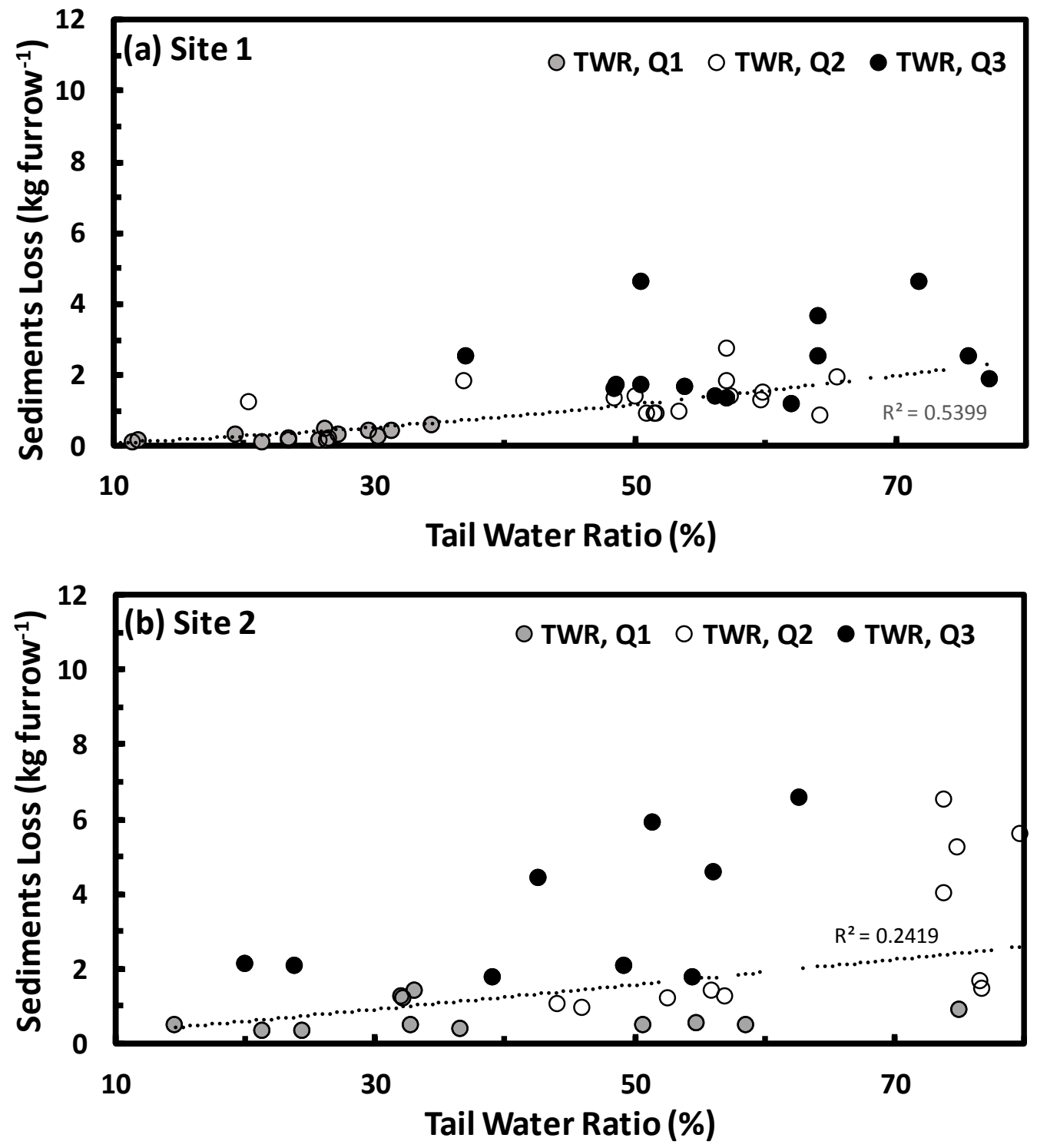

Figure 10 